\title{
Determining the Occurrence of Pesticides and Volatile Organic Compounds in Public Water- Supply Source Waters in Texas
}

Evaluation of the susceptibility of public water supplies to contamination is of nationwide interest. To this end, the U.S. Environmental Protection Agency, through the Safe Drinking Water Act Amendments of 1996, requires the Texas Natural Resource Conservation Commission (TNRCC) to complete a Source Water Assessment. The assessment will include the identification of potential contamination sources and will generate information regarding the susceptibility of public water-supply source waters to contamination. This information will, in turn, help identify source waters that might qualify for less monitoring or that might require additional monitoring. The U.S. Geological Survey, in cooperation with the TNRCC, is collecting ground- and surface-water quality data and using the data to compile a database for use in the Source Water Assessment.

\section{A Need for Sound Data}

One of the requirements for the assessment of susceptibility to contamination of public water-supply source waters is a comprehensive waterquality database. Currently (1999), few data on the quality of Texas drinkingwater sources are available for a number of constituents. Particularly scarce are data on the low-level occurrence of dissolved pesticides and volatile organic compounds (VOCs), including methyl tert-butyl ether (MTBE), which are among the most widespread contaminants in water supplies nation-
Texans trust in the quality of their drinking water. Millions of dollars are spent each year on water-quality monitoring, source-water protection, and water treatment to ensure that this trust is well-founded. These programs are important but expensive.

Just how susceptible are Texas drinking-water supplies to contamination?

Assessment of susceptibility to contamination would enable more efficient use of limited dollars for monitoring and protecting the water supply.

wide (table 1). These data can be used to target those source waters most susceptible to contamination for protection efforts long before contaminants reach levels that pose a risk to public health.

\section{Building a Water-Quality Database}

A comprehensive survey of public water-supply sources in Texas is underway. The reservoirs and wells selected for sampling were chosen to cover a large range in the environmental characteristics that could influence susceptibility to contamination-for example, land use, soil type, and, in the case of wells, aquifer type and depth to water. Some of the sampled water sources might show a limited susceptibility to contamination, and others might show a higher risk. By choosing reservoirs and wells in this way, the importance of each of these factors in causing contamination can be determined.

Forty-eight of the approximately 200 water-supply reservoirs have already been sampled; 44 reservoirs were sampled once, and 4 were sampled twice. One hundred and eighty of the approximately 16,000 public water-supply wells across Texas will be sampled during December 1999-June 2000 (fig. 1). One sample will be collected from each selected public water-supply well before the water has been filtered, chlorinated, or treated in any other way. Samples will be analyzed for 83 dissolved pesticides and 6 VOCs (table 1). In addition, the ground-water samples will be analyzed for tritium to determine the "age" of the water.

\section{Putting the Data to Work}

Water-quality data from this survey will be used to relate the environmental characteristics of the source watersheds or aquifers to the occurrence of contaminants. These relations will be used to predict the likelihood that other, unsampled source waters are at risk. By determining which public water-supply sources are most likely to be contaminated, monitoring and water-quality-protection dollars can be used more efficiently. 


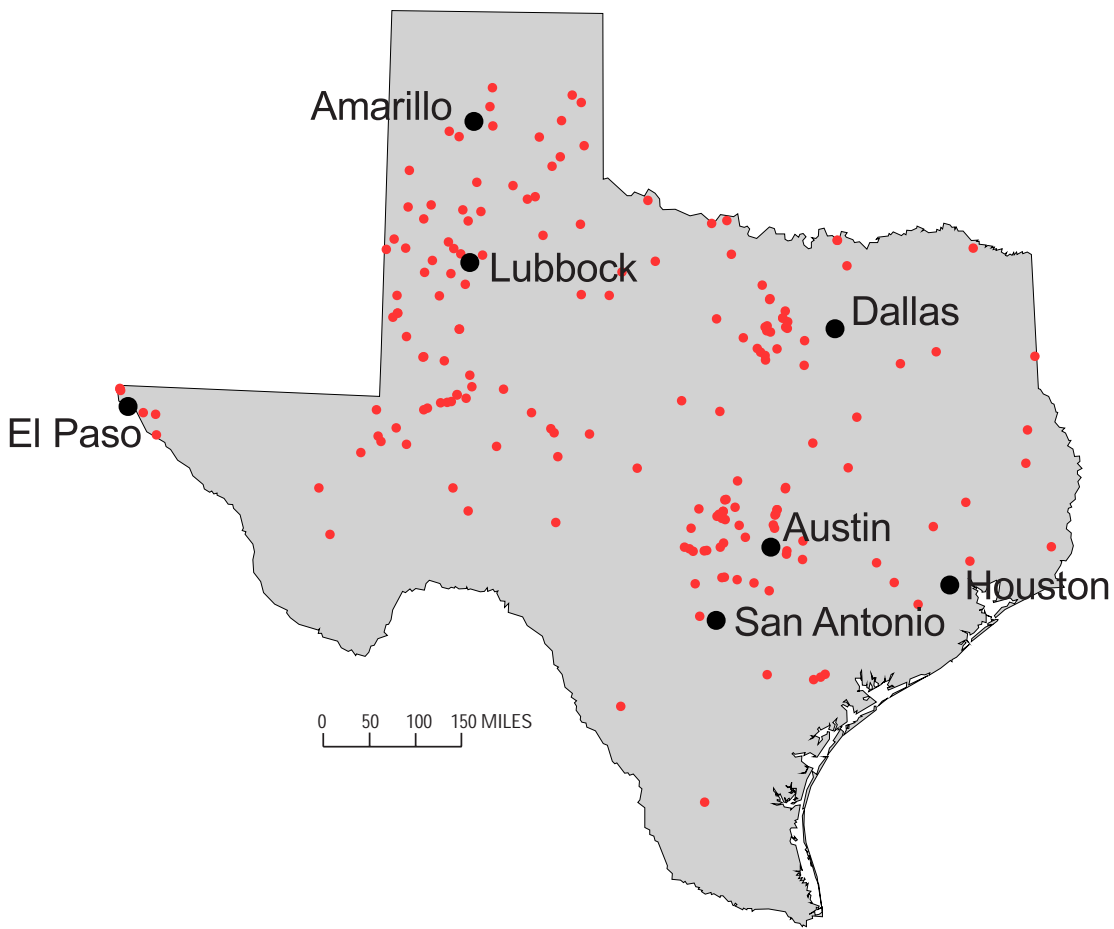

Figure 1. Location of public water-supply wells proposed for sampling.

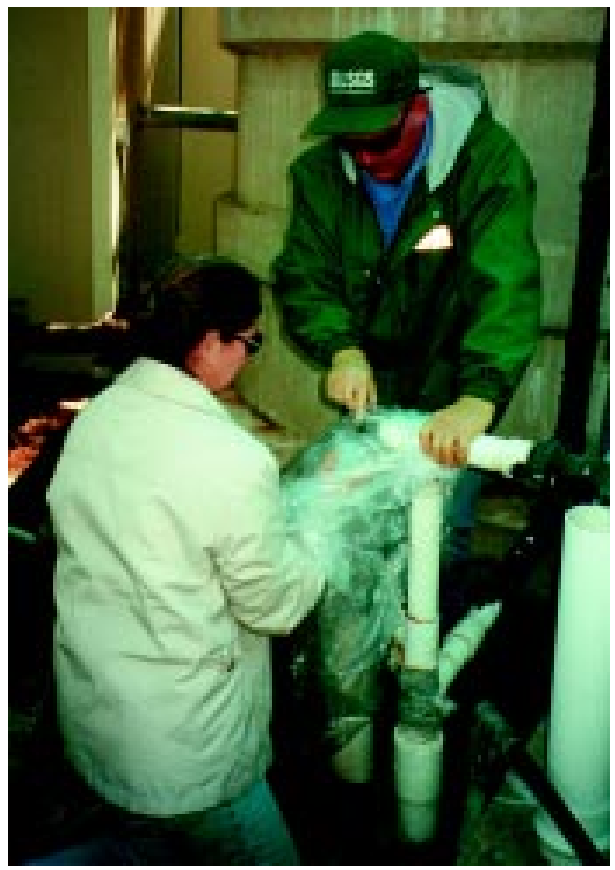

Personnel collecting a sample from a well. The sampling outlet is protected with a sheet of plastic to avoid contamination during sample collection.

Table 1. Dissolved pesticides and volatile organic compounds included in each sample analysis

\begin{tabular}{|c|c|c|c|c|c|}
\hline \multicolumn{6}{|c|}{ Pesticides } \\
\hline Acetochlor & Carbofuran & Dichlobenil & 3-Hydroxycarbofuran & Oryzalin & Propham \\
\hline Acifluorfen & Chloramben & Dieldrin & Lindane & Oxamyl & Propoxur \\
\hline Alachlor & Chlorothalonil & 2,6-Diethylaniline & Linuron & Parathion & Propyzamide \\
\hline Aldicarb & Chlorpyrifos & 4,6-Dinitro-2-methylphenol & Malathion & Parathion-methyl & Simazine \\
\hline Aldicarb sulfone & Clopyralid & Dinoseb & MCPA & Pebulate & $2,4,5-\mathrm{T}$ \\
\hline Aldicarb sulfoxide & Cyanazine & Disulfoton & МСРВ & Pendimethalin & Tebuthiuron \\
\hline Atrazine & Dacthal & Diuron & Methiocarb & cis-Permethrin & Terbacil \\
\hline Azinphos-methyl & Dacthal monoacid & EPTC & Methomyl & Phorate & Terbufos \\
\hline Benfluralin & 2,4-D & Ethalfluralin & Metolachlor & Picloram & Thiobencarb \\
\hline Bentazon & 2,4-DB & Ethoprophos & Metribuzin & $p, p^{\prime}-\mathrm{DDE}$ & 2,4,5-TP \\
\hline Bromacil & Deethylatrazine & Fenuron & Molinate & Prometon & Triallate \\
\hline Bromoxynil & Diazinon & Fonofos & Napropamide & Propachlor & Triclopyr \\
\hline Butylate & Dicamba & Fluometuron & Neburon & Propanil & Trifluralin \\
\hline Carbaryl & Dichloroprop & alpha-HCH & Norflurazon & Propargite & \\
\hline \multicolumn{6}{|c|}{ VOCs } \\
\hline Benzene & Ethylbenzene & MTBE & Toluene & $m$ - and $p$-Xylene & $o$-Xylene \\
\hline
\end{tabular}

\section{- B.J. Mahler}

Any use of trade, product, or firm names is for descriptive purposes only and does not imply endorsement by the U.S. Government.

\section{For more information, please contact:}

District Chief

U.S. Geological Survey

8027 Exchange Dr.

Austin, TX 78754-4733

E-mail: dc_tx@usgs.gov
Phone: (512) 927-3500

FAX: (512) 927-3590

World Wide Web: http://tx.usgs.gov/ 